\title{
Tanggungjawab Notaris Terhadap Penomoran Ganda Pada Akta Yang Berbeda
}

\author{
I Gusti Ayu Oka Trisnasari ${ }^{1}$
}

${ }^{1}$ Program Studi Magister (S2) Kenotariatan Fakultas Hukum Universitas Udayana, BaliIndonesia, E-mail: trisnaanaa@yahoo.co.id

Info Artikel
Masuk : 21 Pebruari 2019
Diterima: 9 April 2019
Terbit: 30 April 2019
Keywords :
Responsibility, Notary, Deed
Numbering
DOI :
10.24843/ AC.2019.v04.i01.p09
Corresponding Author:
E-mail:
trisnaanaa@yahoo.co.id
Panggungjawab, Notaris,

Info Artikel

April 2019

Keywords :

Responsibility, Notary, Deed

Numbering

10.24843/AC.2019.v04.i01.p09

\begin{abstract}
A notary is a public official who has the authority to make an authentic deed. In carrying out its authority to make authentic deeds, a Notary cannot be separated from errors such as including the same deed number on a different deed. The problems contained in this writing are (1) What is the Notary's responsibility for double numbering on different deeds and (2) What are the legal consequences of multiple numbering on different deeds? The purpose of this paper is to analyze and understand the Notary's responsibility for double numbering on different deeds and legal consequences for double numbering on different deeds. This type of research is normative legal research that uses a type of statute approach. The legal material used consists of primary and secondary legal materials. Card system techniques are used as legal material collection techniques and description techniques as techniques for analyzing legal material. The results of the discussion obtained show that (1) the Notary's responsibility for double numbering on different deeds, namely the Notary is charged with civil liability as determined in Article 84 of the UUJN. This responsibility can be carried out by withdrawing a copy of the related deed whose costs are borne by a Notary, this is done because the mistake in numbering the deed can be detrimental to the parties if the deed is used in the verification process, (2) The legal consequences of double numbering on the different deed namely the deed still considered valid if it has fulfilled the legal requirements of an agreement specified in Article 1320 of the Civil Code.
\end{abstract}

\begin{tabular}{l}
\hline Abstrak \\
\hline Notaris ialah pejabat umum yang mempunyai kewenangan \\
untuk membuat suatu akta otentik. Dalam menjalankan \\
kewenangannya membuat akta otentik, Notaris tidak terlepas \\
dari kesalahan seperti mencantumkan nomor akta yang sama \\
pada akta yang berbeda. Permasalahan yang terdapat dalam \\
penulisan ini ialah (1) Bagaimana tanggungjawab Notaris \\
terhadap penomoran ganda pada akta yang berbeda dan (2) \\
Bagaimana akibat hukum atas penomoran ganda pada akta yang \\
berbeda? Tujuan penulisan ini yaitu untuk menganalisis dan \\
memahami mengenai tanggungjawab Notaris terhadap \\
penomoran ganda pada akta yang berbeda dan akibathukum atas \\
penomoran ganda pada akta yang berbeda. Jenis penelitian ini \\
merupakan penelitian hukum normatif yang menggunakan jenis \\
pendekatan perundang-undangan (statute approach). Bahan
\end{tabular}


hukum yang digunakan terdiri dari bahan hukum primer dan sekunder. Teknik sistem kartu (card system) digunakan sebagai teknik pengumpulan bahan hukum dan teknik deskripsi sebagai teknik untuk menganalisis bahan hukum. Hasil pembahasan yang diperoleh menunjukan bahwa (1) Tanggungjawab Notaris terhadap penomoran ganda pada akta yang berbeda yaitu Notaris dibebankan tanggungjawab secara perdata sebagaimana ditentukan dalam Pasal 84 UUJN. Tanggungjawab tersebut dapat dilakukan dengan menarik salinan akta terkait yang biayanya ditanggung oleh Notaris, hal ini dilakukan karena kesalahan dalam penomoran akta dapat merugikan para pihak jika akta tersebut digunakan dalam proses pembuktian, (2) Akibat hukum atas penomoran ganda pada akta yang berbeda yaitu akta tersebut tetap dianggap sah apabila telah memenuhi syarat-syarat sahnya suatu perjanjian yang ditentukan dalam Pasal 1320 KUHPerdata.

\section{Pendahuluan}

Pada umumnya, tindakan hukum yang dilakukan dalam masyarakat dapat dituangkan dalam akta yang berbentuk otentik. Kitab Undang-Undang Hukum Perdata yang kemudian disingkat dengan KUHPerdata mengatur mengenai pengertian akta otentik. Adapun Pasal 1868 dalam KUHPerdata menyatakan bahwa akta otentik merupakan akta yang dibuat berdasarkan ketentuan dalam undangundang dihadapan atau oleh pagawai-pegawai umum yang mempunyai kekuasaan dalam hal tersebut di tempat akta itu dibuat. Pembuatan akta otentik dapat dilakukan melalui suatu jabatan tertentu. Dalam hal ini, jabatan yang diberikan wewenang dalam pembuatan akta otentik yaitu Notaris. Pasal 1 angka 1 Undang-Undang Nomor 2 Tahun 2014 tentang Perubahan Atas Undang-Undang Nomor 30 Tahun 2004 tentang Jabatan Notaris yang kemudian disingkat dengan UUJN-P menyatakan bahwa seorang Notaris merupakan seorang pejabat umum yang berdasarkan UUJN-P dan undangundang lainnya mempunyai kewenangan dalam hal membuat akta otentik dan kewenangan lainnya. Pejabat umum seperti Notaris mempunyai peran dalam memberikan jasa kepada masyarakat berkaitan dengan kewenangannya dalam membuat akta otentik. ${ }^{1}$ Berkaitan dengan hal tersebut, maka akta yang dibuat dalam bentuk otentik dapat digunakan oleh para pihak yang bersangkutan untuk memperoleh kepastian hukum dalam hal pembuktian. Akta yang dibuat secara otentik mempunyai manfaat yaitu dapat digunakan para pihak dalam menyelesaikan sengketa yang terjadi. ${ }^{2}$

Dalam UUJN-P khususnya Pasal 15 ayat (1) mengatur tentang kewenangan Notaris yang bertindak sebagai pejabat umum yang melakukan pembuatan akta otentik. Disamping adanya kewenangan tersebut, terdapat pula tanggungjawab yang dibebankan kepada Notaris jika terdapat pelanggaran ataupun kesalahan yang dilakukan dalam pembuatan akta otentik. UUJN-P mengatur mengenai

1 Pertiwi, S. M., Sirtha, I. N., \& Dharsana, I. M. P. Tanggung Jawab Notaris Terhadap Akta Otentik Yang Berakibat Batal Demi Hukum Pada Saat Berakhir Masa Jabatannya. None, 2.

2 Fitriyeni, C. E. (2012). Tanggung Jawab Notaris terhadap Penyimpanan Minuta Akta sebagai Bagian dari Protokol Notaris. KANUN: Jurnal Ilmu Hukum, 14(3), 391-404. 
tanggungjawab Notaris yang ditentukan dalam Pasal 65 UUJN-P. Pasal tersebut menentukan bahwa segala akta yang dibuat menjadi tanggungjawab Notaris, Notaris pengganti sementara maupun Notaris pengganti. Tanggungjawab tersebut tetap dimiliki oleh Notaris walaupun protokol Notaris telah diberikan kepada pihak yang selanjutnya menyimpan protokol Notaris. Tanggungjawab Notaris terhadap akta yang dibuatnya dimulai dari awal pembuatan akta sampai dengan akhir pembuatan akta.

Namun, dalam prakteknya Notaris dalam membuat akta tidak terlepas dari adanya kesalahan maupun kekeliruan. Notaris dapat saja mengalami kekeliruan dalam penomoran akta yang dibuatnya seperti mencantumkan nomor akta yang sama terhadap akta yang berbeda. Hal tersebut berdampak pada akta yang dibuatnya jika terdapat permasalahan dikemudian hari. Apabila merujuk pada UUJN, maka tidak ditentukan secara jelas mengenai jenis tanggungjawab Notaris apabila melakukan kekeliruan dalam penomoran ganda pada akta yang berbeda. Adapun pemasalahan dalam penulisan ini yaitu mengenai tanggungjawab Notaris terhadap penomoran ganda pada akta yang berbeda dan akibat hukum atas penomoran ganda pada akta yang berbeda.

Tujuan penulisan ini yaitu untuk menganalis dan memahami permasalahan mengenai tanggungjawab Notaris terhadap penomoran ganda pada akta yang berbeda dan akibat hukum atas penomoran ganda pada akta yang berbeda.

\section{Metode Penelitian}

Jenis penulisan yang digunakan bersifat normatif. Jenis pendekatan perundangundangan (statute approach) digunakan karena yang diteliti ialah keterkaitan peraturan atau undang-undang dengan permasalahan yang diteliti. Dalam hal ini, sumber bahan hukum diperoleh melalui data sekunder yang dilakukan melalui kepustakaan atau yang disebut dengan library research. Bahan hukum sangat penting bagi suatu penulisan, yang dalam hal ini menggunakan bahan hukum primer dan sekunder. Bahan hukum primer ini merupakan undang-undang yang mempunyai keterkaitan dengan permasalahan yang diteliti, sedangkan berbagai buku maupun jurnal yang digunakan tergolong bahan hukum sekunder. Selanjutnya, dalam melakukan pengumpulan bahan hukum digunakan teknik sistem kartu. Teknik ini dilakukan dengan mengumpulkan hal-hal penting kemudian mencatatnya. Selain itu, terdapat teknik yang digunakan untuk menganalisis bahan hukum yaitu dengan teknik deskripsi. Teknik ini merupakan teknik dasar dalam menganalisis bahan hukum mengenai suatu kondisi dari proposisi-proposisi hukum maupun tidak dalam hukum. ${ }^{3}$

\section{Hasil dan Pembahasan}

\subsection{Tanggungjawab Notaris Terhadap Penomoran Ganda Pada Akta Yang Berbeda}

Pembuatan akta otentik dapat dilakukan oleh seseorang yang diberikan kewenangan oleh undang-undang dalam melakukan pembuatan akta secara otentik. Kewenangan

\footnotetext{
${ }^{3}$ M. Iqbal Hasan, 2002, Pokok-Pokok Materi Metode Penelitian dan Aplikasinya, Ghalia Indonesia, Jakarta, h. 43.
} 
tersebut dapat dijalankan oleh profesi tertentu seperti Notaris. Profesi sebagai Notaris tersebut telah diberikan kewenangan oleh UUJN dalam melakukan pembuatan akta secara otentik. Dalam hal ini, Notaris merupakan pejabat umum yang mempunyai peran dalam memberikan pelayanan jasa mupun penyuluhan hukum terkait dengan akta otentik kepada masyarakat. Hal ini dilakukan agar para pihak yang kurang memahami hukum terhindar dari penipuan sehingga mendapatkan kepastian hukum mengenai hak dan kewajibannya. Selain berwenang untuk melakukan pembuatan akta secara otentik, Notaris dapat melakukan kewenangannya selain dalam membuat akta otentik. Hal ini ditentukan dalam UUJN-P yaitu Pasal 15 ayat (2) yang menentukan bahwa:

a. Melakukan pengesahan terhadap tanda tangan, serta memastikan waktu suatu surat yang dibuat secara dibawah tangan kemudian mendaftarkannya menggunakan buku yang telah disediakan secara khusus;

b. Melakukan pembukuan terhadap surat yang berbentuk di bawah tangan kemudian mendaftarkannya mengunakan buku yang telah disediakan secara khusus;

c. Melakukan pembuatan salinan sebagaimana tertulis dalam surat yang bersangkutan sebagai kopi asli dari surat yang dibuat secara di bawah tangan;

d. Melakukan pengesahan atas kecocokan kopi surat yang sesuai aslinya;

e. Mengadakan penyuluhan yang berkaitan dengan akta dan pembuatannya;

f. Melakukan pembuatan akta yang dalam hal ini berhubungan dengan tanah;

g. Membuat akta risalah lelang.

Berkaitan dengan hal ini, Notaris yang membuat akta otentik harus berdasarkan kehendak para pihak berkepentingan. Notaris harus memastikan bahwa identitas para pihak yang ditunjukan telah sesuai dengan para pihak yang mengahadap. ${ }^{4}$ Akta otentik yang dibuat oleh Notaris harus berisikan keterangan dan maksud dibuatnya akta tersebut dengan benar. Setelah itu, agar akta yang dibuat dapat dimengerti oleh para pihak yang bersangkutan, maka pembacaan akta sangat penting dalam proses pembuatan akta. Berkaitan dengan hal tersebut, masing-masing pihak akan mendapatkan perlindungan yang dapat diwujudkan dengan adanya akta yang dibuat oleh Notaris. ${ }^{5}$ Disamping itu, untuk membuat suatu akta haruslah tetap memenuhi ketentuan yang berlaku. Hal tersebut dilakukan agar Notaris dalam menjalankan kewenangannya tidak bertindak sewenang-wenang sehingga merugikan para pihak yang bersangkutan. ${ }^{6}$ Tindakan Notaris yang tidak sewenang-wenang dalam membuat akta akan mempengaruhi kualitas akta itu sendiri sehingga akan menjadi otentik dan tidak mempunyai kekuatan pembuktian yang lemah. ${ }^{7}$

\footnotetext{
${ }^{4}$ Intan, L. C. (2016). Akibat pelanggaran oleh notaris terhadap pembuatan akta notariil. Jurnal Cakrawala Hukum, 7(2), 206-215.

5 Diana, P. V. P., Mertha, I. K., \& Artha, I. G. (2015). Pertanggung Jawaban Notaris Dalam Pembuatan Akta Berdasarkan Pemalsuan Surat Oleh Para Pihak. Acta Comitas, 161-172.

6 Prabawa, B. G. A. (2017). Analisis Yuridis Tentang Hak Ingkar Notaris dalam Hal Pemeriksaan Menurut Undang-undang Jabatan Notaris dan Kode Etik Notaris. Acta Comitas, 2, 98-110.

7 Sjaifurrachman, 2011, Aspek Pertanggungjawaban Notaris Dalam Pembuatan Akta, Mandar Maju, Bandung, h. 110.
} 
Selain kewenangan yang dimiliki, adapun kewajiban yang dimiliki oleh Notaris. Kewajiban itu berkaitan dengan prosedur dalam membuat suatu akta otentik. ${ }^{8}$ UUJN-P mengatur kewajiban Notaris yang telah ditentukan dalam Pasal 16 ayat (1). Pasal tersebut mengatur jika Notaris wajib untuk bersikap seksama, tidak berbohong, adil serta mementingkan masing-masing pihak; melakukan pembuatan akta dengan menuangkannya dalam minuta akta yang kemudian disimpan menjadi protokol Notaris; melakukan pelekatan sidik jari para pihak berserta dokumennya dalam minuta; mengeluarkan akta dalam bentuk grosse akta, kutipan maupun salinan yang sesuai dengan minuta; melayani sesuai dengan peraturan yang berlaku; tidak memberitahukan mengenai isi maupun keterangan dalam akta kepada pihak lain; akta yang telah dibuat oleh Notaris selama 1 (satu) bulan dijilid dalam buku yang tidak lebih dari 50 (limapuluh akta), mencatat banyaknya minuta yang telah dibuat dan waktu pembuatan akta pada sampul buku; serta para pihak, Notaris dan saksi menandatangani akta yang telah dibuat; serta menerima magang untuk calon Notaris.

Disamping adanya kewenangan dan kewajibannya, adapun tanggungjawab yang dimiliki dalam menjalankan jabatan sebagai seorang Notaris. UUJN-P mengatur mengenai tanggungjawab Notaris yaitu dalam Pasal 65. Pasal tersebut menentukan bahwa setiap akta yang dibuat merupakan tanggungjawab Notaris, Notaris pengganti maupun pejabat sementara Notaris. Tanggungjawab tersebut tetap dimiliki oleh Notaris walaupun protokol Notaris telah diberikan kepada penyimpan protokol Notaris. Sebagai pejabat umum, Notaris bertanggungjawab mengenai keabsahan akta otentik yang dibuatnya. Notaris dapat dibebani dengan tanggungjawab apabila dalam aktanya mengandung unsur pelanggaran, kelalaian maupun kesalahan. Jika dalam akta yang dibuat oleh Notaris terdapat unsur kesalahan atau pelanggaran yang tidak dilakukan oleh Notaris melainkan oleh penghadap, maka pertanggungjawaban tidak dapat dibebankan kepada Notaris.

Berkaitan dengan itu, tanggungjawab seorang Notaris terhadap aktanya berkaitan dengan kewenangan dan tugas yang dijalaninya. ${ }^{9}$ Pembuatan akta yang dilakukan oleh Notaris harus membutuhkan ketelitian yang dimulai dari awal hingga akhir akta. Awal akta memuat beberapa hal seperti judul dan nomor akta, waktu pembuatan akta, serta nama Notaris dan tempat kedudukannya. Kemudian, badan akta terdapat identitas lengkap para penghadap atau seseorang yang diwakili, kedudukan dan kehendak masing-masing pihak, serta identitas masing-masing saksi. Selanjutnya, dalam akhir atau penutup akta terdapat uraian mengenai akta yang telah dibacakan, penandatanganan akta serta ada atau tidaknya penerjemah, identitas masing-masing saksi dan keterangan mengenai ada atau tidaknya perubahan dalam akta tersebut.

Pembuatan akta otentik yang dilakukan oleh Notaris tidak terlepas dari adanya kesalahan maupun kekeliruan. Dalam hal ini, Notaris dapat mengalami kekeliruan dalam membuat awal akta seperti penomoran akta. Berkaitan dengan hal tersebut, Notaris dapat saja mengalami kekeliruan dalam penomoran akta dengan mencantumkan nomor akta yang sama pada akta yang berbeda. Oleh karena itu,

8 Kusumaningrum, I. A. K., Wairocana, I. G. N., Suartha, M., \& Dewa, I. Kewajiban Saksi Instrumenter Merahasiakan Isi Akta Berdasarkan Undang-undang Jabatan Notaris. Acta Comitas, 2.

9 Hendra, R. (2012). Tanggungjawab Notaris Terhadap Akta Otentik Yang Penghadapnya Mempergunakan Identitas Palsu di Kota Pekanbaru. Jurnal Ilmu Hukum, 3(01). 
kekeliruan yang dilakukan Notaris khususnya mengenai penomoran akta yang sama terhadap akta yang berbeda, maka Notaris yang bersangkutan dapat dibebankan tanggungjawab perdata dengan melakukan penggantian biaya dan ganti rugi. Berkaitan dengan hal tersebut, KUHPerdata khususnya Pasal 1366 mengatur tentang tanggungjawab seseorang atas kerugian yang ditimbulkan akibat perbuatan yang dilakukannya, baik yang dilakukan karena kelalaian maupun ketidakhati-hatiannya.

Tanggungjawab Notaris dapat dibedakan dalam berbagai segi, yaitu tanggungjawab dalam segi pidana, tanggungjawab dalam segi administrasi dan tanggungjawab dalam segi perdata yang dapat dijelaskan sebagai berikut:

a. Tanggungjawab dalam segi administrasi

Tanggungjawab Notaris dalam segi administrasi berkaitan dengan adanya sanksi administratif yang diberikan apabila Notaris melakukan pelanggaran yang ditentukan Pasal 85 Undang-Undang Nomor 30 Tahun 2004 tentang Jabatan Notaris (Lembaran Negara Republik Indonesia Tahun 2004 Nomor 117, Tambahan Lembaran Negara Republik Indonesia Nomor 4432, selanjutnya disebut UUJN). Pasal tersebut menentukan terkait sanksi yang diberikan apabila melakukan pelanggaran tersebut. Sanksi yang diberikan merupakan teguran baik tertulis maupun lisan, pemberhentian yang dilakukan sementara, ataupun pemberhentian yang dilakukan dengan hormat maupun tidak hormat.

b. Tanggungjawab dalam segi pidana

Notaris dapat bertanggungjawab secara pidana jika dalam akta yang dibuatnya terdapat unsur penipuan maupun tipu muslihat yang disebabkan oleh Notaris yang bersangkutan. Tanggungjawab Notaris dalam segi pidana dapat dibebankan kepada Notaris apabila Notaris tersebut telah melanggar ketentuan dalam UUJN, UUJN-P maupun Kitab Undang-Undang Hukum Pidana. Berkaitan dengan itu, apabila Notaris melakukan pelanggaran pidana namun tidak melanggar ketentuan dalan UUJN mapun UUJN-P, maka Notaris tersebut tidak dapat dibebani tanggungjawab secara pidana.

c. Tanggungjawab dalam segi perdata

Tanggungjawab Notaris dalam segi perdata dapat dibebani kepada Notaris apabila Notaris yang bersangkutan melakukan suatu tindakan yang mengakibatkan kerugian bagi penghadap. Pejabat umum seperti Notaris memiliki keterkaitan dengan pembuktian dalam hukum perdata. ${ }^{10}$ Tanggungjawab perdata ditimbulkan dari adanya suatu hubungan hukum yang diadakan masing-masing pihak dengan Notaris. ${ }^{11}$ UUJN telah mengatur mengenai tanggungjawab perdata seorang Notaris yaitu dalam Pasal 84 UUJN. Tanggungjawab Notaris secara perdata yang diatur dalam Pasal 84 UUJN mengatur jika dalam menjalankan tugasnya Notaris melakukan pelanggaran yang menyebabkan akta tersebut berkekuatan seperti akta di bawah tangan

10 Setiabudhi, I. K. R., \& Swardhana, G. M. (2017). Sanksi Hukum Terhadap Notaris Yang Melanggar Kewajiban Dan Larangan Undang-Undang Jabatan Notaris. Acta Comitas, 110-121.

11 Putri, K. P. Tanggung Jawab Dan Perlindungan Hukum Bagi Notaris Purna Bakti Terhadap Akta Yang Pernah Dibuat (Analisis Pasal 65 Dan Pasal 66 Undang-undang Nomor 2 Tahun 2014 Tentang Perubahan Atas Undang-undang Nomor 30 Tahun 2004 Tentang Jabatan Notaris). Jurnal Mahasiswa Fakultas Hukum Universitas Brawijaya. 
atau batal demi hukum, ataupun yang merugikan para pihak, maka para pihak tersebut mempunyai hak untuk menuntut Notaris mengganti rugi dan mengganti biaya yang telah digunakan.

Dalam hal ini, teori tanggungjawab dapat digunakan dalam menganalisis permasalahan mengenai penomoran ganda pada akta yang berbeda. Teori tanggungjawab dikemukakan oleh Hans Kelsen. Menurut teori tanggungjawab, seseorang dapat dibebankan tanggungjawab secara hukum atas perbuatan tertentu yang dilakukannya. Seseorang mempunyai tanggungjawab atas sanksi yang diberikan dalam hal perilaku yang bertentangan. ${ }^{12}$ Adapun teori mengenai pertanggungjawaban hukum yang dikemukakan oleh Kranenburg dan Vegtig yaitu:

a. Teori fautes de service, merupakan teori yang menyatakan jika kerugian yang dialami oleh pihak ketiga dibebankan kepada instansi dari pejabat yang bersangkutan. Berdasarkan teori ini, tanggungjawab yang dibebankan berkaitan pula dengan berat atau ringannya suatu kesalahan yang dilakukan.

b. Teori fautes personelles, merupakan teori yang menyatakan jika kerugian yang dialami oleh pihak ketiga dibebankan kepada pejabat yang telah menimbulkan kerugian. Tanggungjawab ini ditujukan kepada manusia selaku pribadi. ${ }^{13}$

Berdasarkan teori tanggungjawab, maka Notaris sebagai pejabat dapat dibebankan tanggungjawab secara pribadi dalam hal terjadi kerugian akibat penomoran ganda pada akta yang berbeda. Tanggungjawab tersebut dibebankan kepada Notaris karena dengan adanya penomoran akta yang sama pada akta yang berbeda akan menimbulkan kerugian bagi para pihak yang bersangkutan khususnya berkaitan dengan pembuktian. Hal tersebut dikarenakan apabila terdapat akta berbeda yang mempunyai nomor yang sama, maka akan mempersulit proses pembuktian tersebut sehingga akan merugikan para pihak. Oleh karena itu, maka Notaris diwajibkan untuk menarik salinan akta yang terkait dan melakukan pembetulan yang biayanya akan ditanggung oleh Notaris.

\subsection{Akibat Hukum Atas Penomoran Ganda Pada Akta Yang Berbeda}

Notaris merupakan profesi yang mempunyai keterkaitan dengan etika dan moral dalam menjalankan tugasnya. Notaris merupakan pejabat publik yang memiliki tugas untuk mewakili negara dalam hal memberikan pelayanan hukum kepada masyarakat. ${ }^{14}$ Dalam hal ini, Notaris berbeda dengan pejabat publik di bidang pemerintahan karena mempunyai produk hukum yang berbeda. Keberadaan Notaris sebagai pejabat publik didukung dengan adanya kewenangan yang diberikan oleh UUJN. Oleh karena itu, maka Notaris dalam melakukan perbuatan harus didasari dengan kewenangan yang diberikan tersebut. Notaris dalam membuat akta otentik

12 Hans Kelsen, 2007, General Theory Of Law \& State, Teori Umum Hukum dan Negara: Dasar-Dasar Ilmu Hukum Normatif Sebagai Ilmu Hukum Deskriptif-Empirik, terjemahan Somardi, BEE Media Indonesia, Jakarta, h. 81.

${ }^{13}$ Ridwan H.R, 2006, Hukum Administrasi Negara, PT Raja Grafindo Persada, Jakarta, h. 365.

14 Suhariyanto, B. (2018). Penyelesaian Disparitas Putusan Pemidanaan terhadap “Kriminalisasi" Kebijakan Pejabat Publik. Jurnal Penelitian Hukum De Jure, 18(3), 353-366. 
tidak boleh sewenang-wenang dan harus berlandaskan pada peraturan perundangundangan. Apabila terjadi permasalahan dikemudian hari diantara para pihak, maka akta yang dibuat oleh Notaris dapat digunakan sebagai alat bukti yang kuat. Akta otentik dapat mengikat masing-masing pihak yang bersangkutan karena akta tersebut berkekuatan sempurna dalam hal pembuktian. Selain itu, dalam pembuktian Hakim harus menjadikan suatu akta otentik sebagai bukti yang cukup dalam penyelesaian masalah. Apabila kebenaran suatu akta otentik ingin disangkal, maka akta tersebut harus dibuktikan bahwa akta tersebut terdapat kepalsuan.

Notaris dalam membuat akta otentik tentunya tidak terlepas dari adanya kekeliruan atau kesalahan yang berdampak pada kerugian. Perbuatan yang demikian dikenal dengan istilah mal administrasi. Pasal 1 angka 3 Undang-Undang Nomor 37 Tahun 2008 tentang Ombudsman Republik Indonesia mengatur mengenai definisi mal administrasi yaitu perbuatan melawan hukum, melampaui wewenang, tidak menggunakan wewenang sesuai dengan tujuannya, termasuk kelalaian ataupun pengabdian kewajiban hukum dalam penyelenggara negara dan pemerintahan yang mengakibatkan kerugian materiil dan/atau imateriil bagi masyarakat dan orang perseorangan. Suatu mal administrasi dapat terjadi dalam hal penomoran akta seperti melakukan penomoran akta dengan nomor yang sama pada akta yang berbeda. Hal ini dapat terjadi karena adanya kekeliruan yang dilakukan dalam pembuatan akta otentik. Adanya kesalahan tersebut dapat dikategorikan sebagai mal administrasi sehingga mengakibatkan cacat substansi terhadap akta yang dibuat.

Notaris dalam membuat akta otentik diwajibkan untuk melakukan penomoran dalam setiap akta yang dibuatnya. Hal ini merupakan salah satu unsur yang terdapat dalam awal akta dan harus dipenuhi dalam pembuatan akta otentik. Penomoran yang dilakukan dalam akta bertujuan untuk memperjelas urutan dalam setiap pembuatan akta yang dilakukan oleh Notaris. Namun, apabila terdapat penomoran ganda pada akta yang berbeda, maka hal ini dapat menimbulkan kebingungan dalam penentuan akibat hukumnya. Apabila itu terjadi, maka akta yang mempunyai nomor yang ganda dengan akta lainnya akan tetap dianggap sah dan berkekuatan sempurna jika isi dari akta tersebut telah memenuhi syarat-syarat sahnya suatu perjanjian.

Notaris dalam membuat akta otentik yang sah diwajibkan untuk berpedoman pada Pasal 1320 KUHPerdata yang mengatur mengenai perjanjian yang dianggap sah. Pasal tersebut mengatur bahwa perjanjian harus didasarkan dari kesepakatan masingmasing pihak, dalam membuat perjanjian para pihak harus cakap, terdapat objek dalam perjanjian itu, serta perjanjian tidak boleh melanggar ketentuan perundangundangan. Namun, kesepakatan dalam perjanjian tidak dapat dianggap sah jika disebabkan oleh adanya kekhilafan, paksaan dan penipuan. Hal ini telah diatur KUHPerdata yaitu dalam Pasal 1321. Pasal ini menentukan jika kesepakatan didasarkan karena paksaan, kekhilafan maupun penipuan, maka tidak dapat dianggap sebagai kesepakatan yang sah. Seseorang yang mempunyai kemampuan untuk melakukan perbuatan hukum ialah orang yang mempunyai kecakapan. Pasal 1330 KUHPerdata mengatur mengenai kriteria tidak cakapnya seseorang ialah orang-orang yang masih dibawah umur, seseorang yang di bawah pengampuan, perempuan yang dalam hal-hal ditentukan oleh undang-undang serta seseorang yang dilarang mengadakan kesepakatan tertentu oleh undang-undang. 
Masing-masing pihak dalam mengadakan perjanjian diwajibkan pula mencantumkan objek yang jelas, sehingga kewajiban dan hak masing-masing pihak dapat dilakukan dalam hal pemenuhan prestasi. Selain itu, perjanjian yang dibuat harus mempunyai sebab yang halal dan tidak melanggar undang-undang. Pasal 1337 dalam KUHPerdata mengatur jika melanggar ketentuan undang-undang, ketertiban umum serta kesusilaan merupakan hal-hal yang dilarang dalam perjanjian. Keempat syarat tersebut harus terpenuhi dalam hal membuat akta otentik, sehingga akta yang dibuat menjadi sah dan dapat mengikat pihak yang bersangkutan. Syarat-syarat tersebut dapat digolongkan berdasarkan dengan subyek dan obyeknya. Syarat subyektif meliputi syarat pertama dan kedua, adapun syarat obyektif yang merupakan syarat ketiga dan keempat. Apabila perjanjian tidak memenuhi syarat subyektif yaitu tidak adanya kesepakatan dan kecakapan, maka perjanjian itu dapat dibatalkan masingmasing pihak. Kemudian, jika perjanjian tidak memenuhi syarat objektif yaitu tidak adanya objek perjanjian dan melanggar ketentuan undang-undang, maka perjanjian itu dianggap batal demi hukum dan dianggap tidak pernah ada.

\section{Kesimpulan}

Tanggungjawab dapat dibebankan kepada Notaris apabila akta yang dibuatnya merugikan para pihak yang bersangkutan. Penomoran ganda pada akta yang berbeda dapat merugikan para pihak jika akta tersebut digunakan dalam proses pembuktian karena dapat meragukan pihak ketiga dalam penentuan urutan pembuatan akta. Oleh karena itu, maka Notaris dapat dibebankan tanggungjawab perdata sebagaimana ditentukan dalam Pasal 84 UUJN yaitu Notaris diwajibkan untuk mengganti rugi dan mengganti biaya yang telah digunakan karena akta yang dibuatnya merugikan para pihak. Notaris diwajibkan untuk menarik salinan akta yang terkait dan melakukan pembetulan yang biayanya akan ditanggung oleh Notaris. Akibat hukum atas adanya penomoran ganda pada akta yang berbeda yaitu akta tersebut tetap dianggap sah apabila telah memenuhi ketentuan Pasal 1320 KUHPerdata dan tidak ada putusan pengadilan yang menyebutkan jika akta itu tidak sah.

Notaris dalam membuat akta otentik hendaknya selalu teliti sehingga tidak terjadi kekeliruan yang nantinya akan merugikan para pihak dan Notaris itu sendiri.

\section{Daftar Pustaka \\ $\underline{\text { Buku }}$}

Budiono, Herlien, 2013, Kumpulan Tulisan Hukum Perdata di Bidang Kenotariatan, PT Citra Aditya Bakti, Bandung, h. 219.

Kelsen, Hans, 2007, General Theory Of Law \& State, Teori Umum Hukum dan Negara: Dasar-Dasar Ilmu Hukum Normatif Sebagai Ilmu Hukum Deskriptif-Empirik, terjemahan Somardi, BEE Media Indonesia, Jakarta, h. 81

Sjaifurrachman, 2011, Aspek Pertanggungjawaban Notaris Dalam Pembuatan Akta, Mandar Maju, Bandung, h. 110.

\section{Jurnal}

Diana, P. V. P., Mertha, I. K., \& Artha, I. G. (2015). Pertanggung Jawaban Notaris Dalam Pembuatan Akta Berdasarkan Pemalsuan Surat Oleh Para Pihak. Acta Comitas, 161-172.

Fitriyeni, C. E. (2012). Tanggung Jawab Notaris terhadap Penyimpanan Minuta Akta sebagai Bagian dari Protokol Notaris. KANUN: Jurnal Ilmu Hukum, 14(3), 391-404. 
Hendra, R. (2012). Tanggungjawab Notaris Terhadap Akta Otentik Yang Penghadapnya Mempergunakan Identitas Palsu di Kota Pekanbaru. Jurnal Ilmu Hukum, 3(01).

Intan, L. C. (2016). Akibat pelanggaran oleh notaris terhadap pembuatan akta notariil. Jurnal Cakrawala Hukum, 7(2), 206-215.

Kusumaningrum, I. A. K., Wairocana, I. G. N., Suartha, M., \& Dewa, I. Kewajiban Saksi Instrumenter Merahasiakan Isi Akta Berdasarkan Undang-undang Jabatan Notaris. Acta Comitas, 2.

Pertiwi, S. M., Sirtha, I. N., \& Dharsana, I. M. P. Tanggung Jawab Notaris Terhadap Akta Otentik Yang Berakibat Batal Demi Hukum Pada Saat Berakhir Masa Jabatannya. None, 2.

Prabawa, B. G. A. (2017). Analisis Yuridis Tentang Hak Ingkar Notaris dalam Hal Pemeriksaan Menurut Undang-undang Jabatan Notaris dan Kode Etik Notaris. Acta Comitas, 2, 98-110.

Putri, K. P. Tanggung Jawab Dan Perlindungan Hukum Bagi Notaris Purna Bakti Terhadap Akta Yang Pernah Dibuat (Analisis Pasal 65 Dan Pasal 66 Undangundang Nomor 2 Tahun 2014 Tentang Perubahan Atas Undang-undang Nomor 30 Tahun 2004 Tentang Jabatan Notaris). Jurnal Mahasiswa Fakultas Hukum Universitas Brawijaya.

Setiabudhi, I. K. R., \& Swardhana, G. M. (2017). Sanksi Hukum Terhadap Notaris Yang Melanggar Kewajiban Dan Larangan Undang-Undang Jabatan Notaris. Acta Comitas, 110-121.

Suhariyanto, B. (2018). Penyelesaian Disparitas Putusan Pemidanaan terhadap "Kriminalisasi" Kebijakan Pejabat Publik. Jurnal Penelitian Hukum De Jure, 18(3), 353-366.

\section{Peraturan Perundang-Undangan}

Kitab Undang-Undang Hukum Perdata;

Indonesia, Undang-Undang Nomor 30 Tahun 2004 tentang Jabatan Notaris (Lembaran Negara Republik Indonesia Tahun 2004 Nomor 117, Tambahan Lembaran Negara Republik Indonesia Nomor 4432);

Indonesia, Undang-Undang Nomor 37 Tahun 2008 tentang Ombudsman Republik Indonesia (Lembaran Negara Republik Indonesia Tahun 2008 Nomor 139, Tambahan Lembaran Negara Republik Indonesia Nomor 4899).

Indonesia, Undang-Undang Nomor 2 Tahun 2014 tentang Perubahan Atas UndangUndang Nomor 30 Tahun 2004 tentang Jabatan Notaris (Lembaran Negara Republik Indonesia Tahun 2014 Nomor 3, Tambahan Lembaran Negara Republik Indonesia Nomor 5491). 